Prepared in cooperation with the Village of La Rue, Marion County Commissioners, Montgomery Township, and Marion County Scioto River Conservancy

\title{
Flood-Inundation Maps for the Scioto River at La Rue, Ohio
}

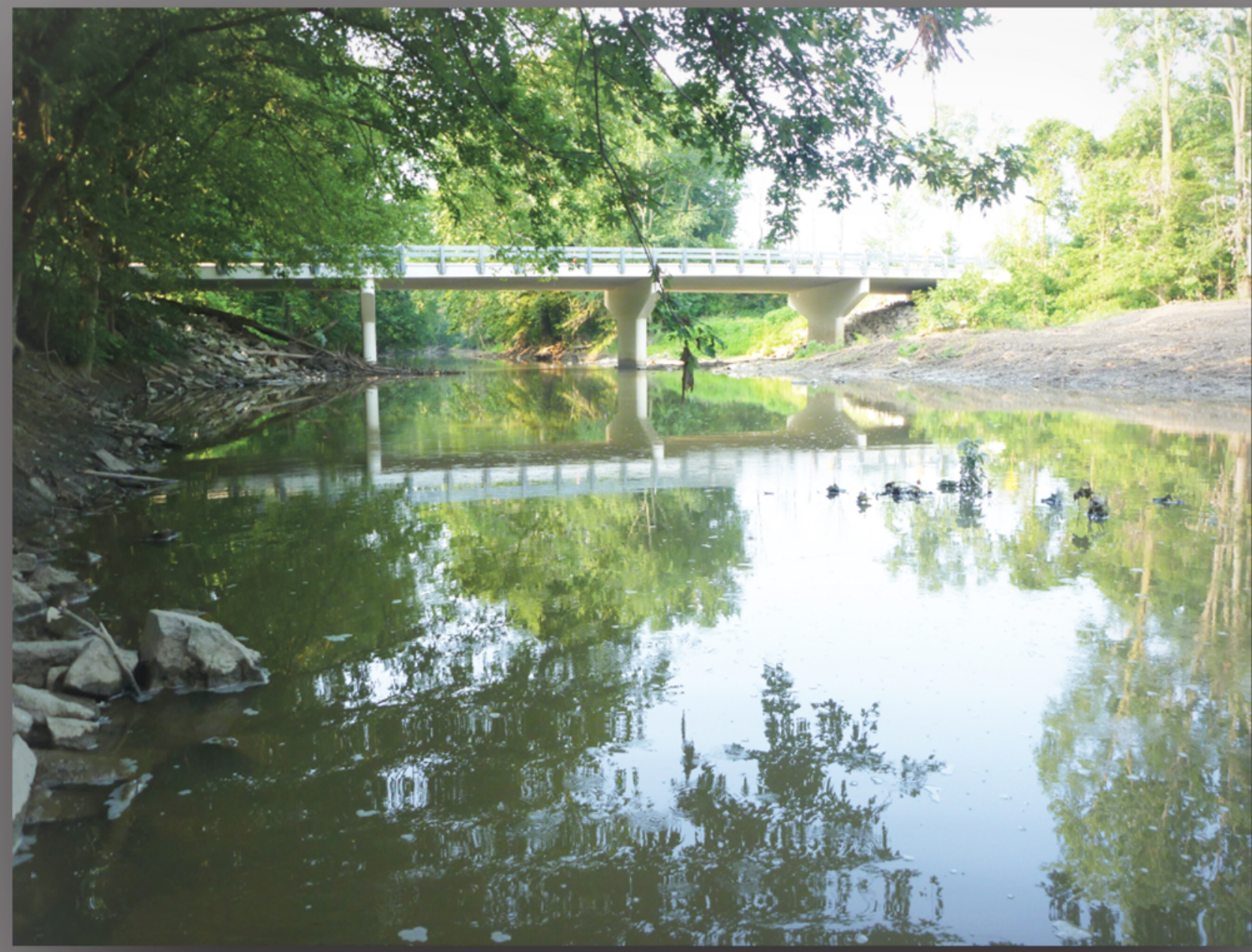

Scientific Investigations Report 2015-5100

U.S. Department of the Interior U.S. Geological Survey 
Cover: View looking downstream at State Route 37 (High Street) bridge over the Scioto River at La Rue, Ohio. (Photo by U.S. Geological Survey, September 2014.) 


\section{Flood-Inundation Maps for the Scioto River at La Rue, Ohio}

By Matthew T. Whitehead

Prepared in cooperation with the Village of La Rue, Marion County

Commissioners, Montgomery Township, and Marion County Scioto River

Conservancy

Scientific Investigations Report 2015-5100 


\title{
U.S. Department of the Interior SALLY JEWELL, Secretary
}

\section{U.S. Geological Survey Suzette M. Kimball, Acting Director}

\author{
U.S. Geological Survey, Reston, Virginia: 2015
}

For more information on the USGS - the Federal source for science about the Earth, its natural and living resources, natural hazards, and the environment—visit http://www.usgs.gov or call 1-888-ASK-USGS.

For an overview of USGS information products, including maps, imagery, and publications, visit http://www.usgs.gov/pubprod/.

Any use of trade, firm, or product names is for descriptive purposes only and does not imply endorsement by the U.S. Government.

Although this information product, for the most part, is in the public domain, it also may contain copyrighted materials as noted in the text. Permission to reproduce copyrighted items must be secured from the copyright owner.

Suggested citation:

Whitehead, M.T., 2015, Flood-inundation maps for the Scioto River at La Rue, Ohio: U.S. Geological Survey Scientific Investigations Report 2015-5100, 11 p., http://dx.doi.org/10.3133/sir20155100.

ISSN 2328-0328 (online) 


\section{Contents}

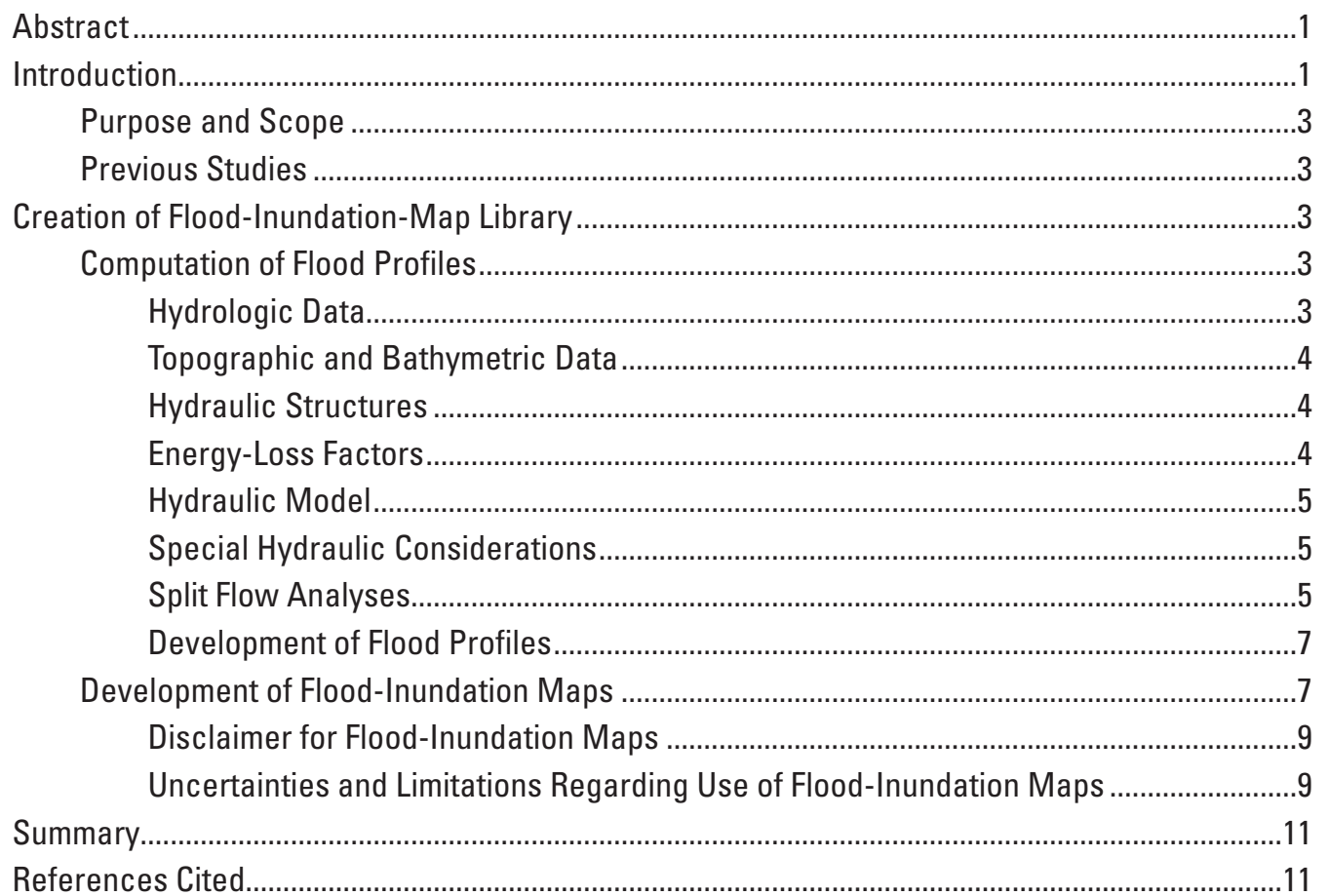




\section{Figures}

1. Map showing location of study reach for the Scioto River at La Rue, Ohio, and

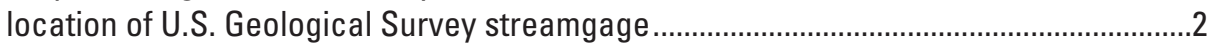

2. Map showing location of overflow culvert near upper end of study reach ......................6

3. Photograph of flood-control cap on west side of La Rue Kenton Road .............................7

4. Map showing representation of split flow analyses for Scioto River at La Rue, Ohio, streamgage...

5. Map showing flood-inundation map for the Scioto River at La Rue, Ohio, corresponding to a stage of 18.0 feet at the U.S. Geological Survey streamgage (03217500).

\section{Tables}

1. U.S. Geological Survey streamgage information for Scioto River at La Rue, Ohio ...........3

2. Stages, corresponding discharges, and water-surface elevations at USGS streamgage used in the hydraulic model of the Scioto River at La Rue, Ohio

3. Calibration of model to target water-surface elevations at U.S. Geological Survey streamgage Scioto River at La Rue, Ohio (03217500).

4. Calibration of model to water-surface elevations at selected locations along the Scioto River for the flood of December 2013.

5. Flow apportionment for split flow analyses for HEC-RAS model for stages at Scioto River at La Rue, Ohio, streamgage 


\section{Conversion Factors}

Inch/Pound to SI

\begin{tabular}{lcl}
\hline \multicolumn{1}{c}{ Multiply } & By & \multicolumn{1}{c}{ To obtain } \\
\hline foot $(\mathrm{ft})$ & Length & meter $(\mathrm{m})$ \\
mile $(\mathrm{mi})$ & 0.3048 & kilometer $(\mathrm{km})$ \\
\hline & 1.609 & \\
\hline square mile $\left(\mathrm{mi}^{2}\right)$ & Area & square kilometer $\left(\mathrm{km}^{2}\right)$ \\
\hline & 2.59 & \\
\hline cubic foot per second $\left(\mathrm{ft}^{3} / \mathrm{s}\right)$ & Flow rate & cubic meter per second $\left(\mathrm{m}^{3} / \mathrm{s}\right)$ \\
\hline
\end{tabular}

Vertical coordinate information is referenced to (1) stage, the height above an arbitrary datum established at a streamgage, and (2) elevation, the height above the North American Vertical Datum of 1988 (NAVD 88).

Horizontal coordinate information is referenced to the North American Datum of 1983 (NAD 83). 



\title{
Flood-Inundation Maps for the Scioto River at La Rue, Ohio
}

\author{
By Matthew T. Whitehead
}

\section{Abstract}

Digital flood-inundation maps for a 3-mile (mi) reach of the Scioto River that extends about 1/2 mi upstream and 1/2 mi downstream of the corporate boundary for La Rue, Ohio, were created by the U.S. Geological Survey (USGS) in cooperation with the Village of La Rue, Marion County Commissioners, Montgomery Township, and Marion County Scioto River Conservancy. The flood-inundation maps show estimates of the areal extent and depth of flooding corresponding to selected water levels (stages) at the USGS streamgage on the Scioto River at La Rue (station number 03217500). The maps can be accessed through the USGS Flood Inundation Mapping Science Web site at http://water.usgs.gov/osw/flood inundation/. Near-real-time stages at this streamgage can be obtained from the USGS National Water Information System at http://waterdata.usgs.gov/oh/nwis/uv/?site_no=03217500 or the National Weather Service (NWS) Advanced Hydrologic Prediction Service at http://water.weather.gov/ahps2/ hydrograph.php?wfo=cle\&gage $=$ LARO1, which also forecasts flood hydrographs at this site.

Flood profiles were computed for the stream reach by means of the one-dimensional step-backwater model HEC-RAS. The model was calibrated by using the current stage-discharge relation at the Scioto River at La Rue, Ohio, streamgage and two locations: the streamgage itself and a single high-water mark from a flood in December 2013.

The step-backwater model was used to determine 11 flood profiles for flood stages ranging from 8 to 18 feet (ft). The National Weather Service defines the "Major Flood Stage" for this gage as $14.0 \mathrm{ft}$. The flood profiles were then used in combination with a digital elevation model (DEM), derived from light detection and ranging (lidar) data having a $1.0-\mathrm{ft}$ vertical accuracy and $1.0-\mathrm{ft}$ horizontal resolution, to delineate the area flooded at each stage.

The availability of these maps, along with Internet information regarding current stage from the USGS streamgage and forecasted high-flow stages from the NWS, will provide emergency management personnel and residents with information that is critical for flood response activities such as evacuations and road closures, as well as for postflood recovery efforts.

\section{Introduction}

La Rue is in north-central Ohio, near the western edge of Marion County (fig. 1). The Scioto River flows toward the village from the northwest and then turns east, demarcating the western and the southern edges of the cooperate limits of La Rue. The estimated population is over 700 people (U.S. Bureau of Census, 2013). The Ohio Emergency Management Agency (OEMA) estimates that 101 flood-insurance policies are currently in effect in La Rue, with a total annual premium of \$63,258 (Steve Ferryman, Ohio Department of Natural Resources, written commun., January 2014). As of November 2013, the insured losses paid for La Rue totaled about \$1.08 million (Christopher Thoms, Ohio Department of Natural Resources, written commun., January 2014). The most recent flooding occurred in February 2011 and December 2013 with peak stages of 14.13 feet $(\mathrm{ft})$ and $14.18 \mathrm{ft}$, respectively.

Prior to this study, emergency responders in La Rue relied on several information sources to make decisions on how to best alert the public and mitigate flood damages. One source is the FEMA Flood Insurance Study (FIS) for Marion County, Ohio, dated July 6, 2010 (Federal Emergency Management Agency, 2010). A second source of information is the USGS streamgage on the Scioto River at La Rue, for which current (U.S. Geological Survey, 2015a) and historical (since 1926; U.S. Geological Survey, 2015b) stages and discharges, including annual peak flows, can be obtained. A third source of flood-related information is the National Weather Service (NWS) Advanced Hydrologic Prediction Service (AHPS), which displays the USGS stage data from the La Rue streamgage and also shows forecasts of stage for the streamgage (National Weather Service, 2015a).

Although stage at a USGS streamgage is particularly useful, it is difficult to translate into depth and areal extent of flooding at points distant from the streamgage. A library of flood-inundation maps referenced to the stage at the USGS streamgage enables users to discern the severity of flooding (depth of water and areal extent). The maps assist emergency managers in identifying roads that are or will be flooded and in making plans for notification or evacuation of residents in danger from floodwaters. In addition, the capability to visualize 


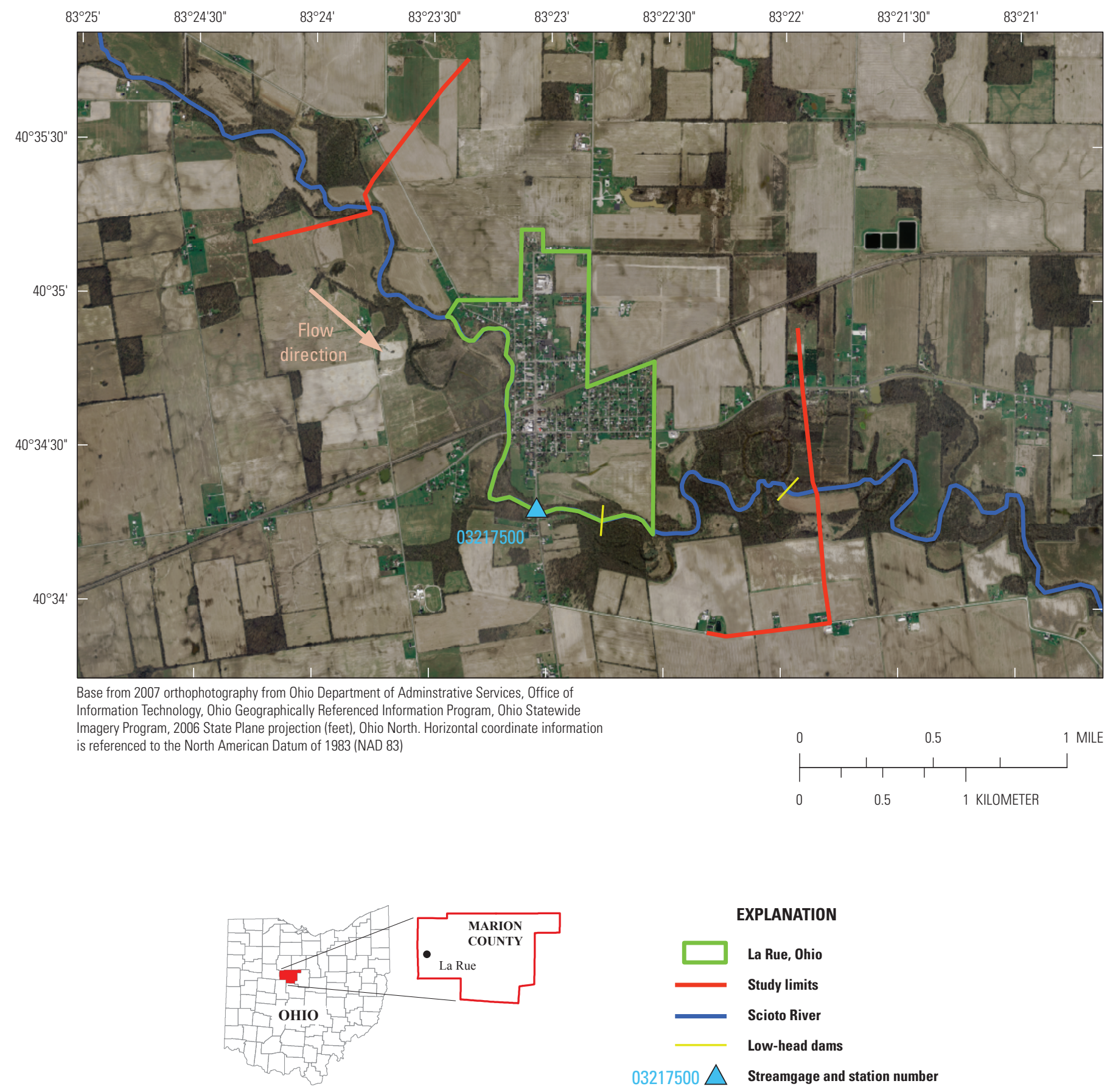

Figure 1. Location of study reach for the Scioto River at La Rue, Ohio, and location of U.S. Geological Survey streamgage. 
the potential extent of flooding may motivate residents to take precautions and heed warnings that they previously might have disregarded.

\section{Purpose and Scope}

This report describes the development of a series of flood-inundation maps for the Scioto River at La Rue, Ohio, and identifies where on the Internet the maps and ancillary data (geographic-information-system flood polygons and depth grids) can be downloaded.

The study reach consists of a 3-mile (mi) segment of the Scioto River that extends approximately $1 / 2$ mi upstream and 1/2 mi downstream of the corporate limits of La Rue (fig. 1). The maps were produced for flood levels referenced to the stage recorded at the USGS streamgage on the Scioto River at La Rue (table 1); the gage is near the middle of the reach.

The maps correspond to stages ranging from 8 to $18 \mathrm{ft}$ at the La Rue streamgage. The 8 - $\mathrm{ft}$ stage is defined by the NWS (2015b) as the "Action Stage" or that stage which, when reached by a rising stream, requires the NWS or a partner to take some type of mitigation action in preparation for possible significant hydrologic activity. The 18 -ft stage exceeds the highest historical crest of $17.80 \mathrm{ft}$ (occurring in 1913) and is significantly higher than the second highest historical crest of $15.95 \mathrm{ft}$ (occurring in 1963).

Table 1. U.S. Geological Survey streamgage information for Scioto River at La Rue, Ohio.

[Station location is shown in figure 1. NAVD 88, North American Vertical Datum of 1988]

\begin{tabular}{|c|c|}
\hline Station name & Scioto River at La Rue \\
\hline Station number & 3217500 \\
\hline Drainage area (square miles) & 257 \\
\hline Latitude & $40^{\circ} 34^{\prime} 19^{\prime \prime}$ \\
\hline Longitude & $83^{\circ} 23^{\prime} 03^{\prime \prime}$ \\
\hline Period of record & $\begin{array}{l}1926 \text { to } 1935 \\
1938 \text { to } 1959 \\
2009 \text { to current }\end{array}$ \\
\hline $\begin{array}{l}\text { Maximum stage, in feet, gage } \\
\text { datum (elevation) and date }\end{array}$ & $\begin{array}{l}17.8 \text { feet } \\
\text { (927.49 feet NAVD 88), } \\
\text { Mar. } 26,1913\end{array}$ \\
\hline
\end{tabular}

\section{Previous Studies}

The effective FIS for Marion County (Federal Emergency Management Agency, 2010) was published in 2010 and includes the reach of the Scioto River through La Rue. Some FISs are re-presentations or compilations of earlier studies; therefore, the date of the hydraulic model that was used to generate the flood profiles presented in the FIS is uncertain. For the flood-inundation-map library, the USGS created a hydraulic model that utilized contemporary data sources and updated elevation data.

\section{Creation of Flood-Inundation-Map Library}

The USGS has standardized the procedures for creating flood-inundation maps for flood-prone communities (U.S. Geological Survey, 2015c) so that the process followed and products produced are similar, regardless of which USGS office is responsible for the work. Tasks specific to development of the flood maps were (1) collection of topographic and bathymetric data for selected cross sections and geometric data for structures and bridges along the study reach, (2) estimation of energy-loss factors (roughness coefficients) in the stream channel and flood plain (3) computation of flood profiles by using the U.S. Army Corps of Engineers' HEC-RAS computer program (U.S. Army Corps of Engineers, 2010), (4) production of flood-inundation maps at various stream stages by using the U.S. Army Corps of Engineers' HEC-GeoRas computer program (U.S. Army Corps of Engineers, 2009) and a geographic information system (GIS), and (5) preparation of the data (shapefiles and depth grids) for display on the USGS floodinundation mapping application.

\section{Computation of Flood Profiles}

The flood profiles used to develop the flood-inundation maps for this study were determined by use of HEC-RAS, version 4.1.0 (U.S. Army Corps of Engineers, 2010). HECRAS is a one-dimensional step-backwater model for determining flood profiles under steady-state or unsteady-state flow conditions. All profiles developed for this report were run within HEC-RAS, using the steady-state flow condition.

\section{Hydrologic Data}

The study reach contains one streamgage that has been in operation at the current location since October 2009 (station number 03217500; fig. 1; table 1). Stage is measured every 15 minutes, transmitted hourly by a satellite radio in the streamgage, and made available on the Internet through the USGS National Water Information System: Web Interface (NWISWeb; U.S. Geological Survey, 2015b). Stage data 
reported for this streamgage can be converted to water-surface elevations referenced to NAVD 88 by adding $909.69 \mathrm{ft}$. Time series of streamflow are computed from a stage-discharge relation developed for the streamgage and are available through the USGS NWISWeb site.

The peak flows used in the model simulations (table 2) were determined for the target stages ( 8 to $18 \mathrm{ft}$ ) from the current stage-discharge relation (rating 2, effective 2014). Rating 2 was available only up to a stage of $15.0 \mathrm{ft}$. The USGS used the calibrated HEC-RAS model that was developed for this study to extend the rating to $18.0 \mathrm{ft}$, creating rating 2.1 . No major tributaries join the Scioto River within the 3-mi study reach; therefore, the discharges held constant throughout the study reach for each profile.

\section{Topographic and Bathymetric Data}

Cross-section elevation data were obtained from a digital elevation model (DEM) that was derived from light detection and ranging (lidar) data that were collected during March

Table 2. Stages, corresponding discharges, and water-surface elevations at USGS streamgage used in the hydraulic model of the Scioto River at La Rue, Ohio.

[ft, feet; $\mathrm{ft}^{3} / \mathrm{s}$, cubic feet per second; NAVD 88, North American Vertical Datum of 1988]

\begin{tabular}{|c|c|c|}
\hline $\begin{array}{l}\text { Stage } \\
(\mathrm{ft})^{1}\end{array}$ & $\begin{array}{c}\text { Discharge } \\
\left(\mathrm{ft}^{3} / \mathrm{s}\right)\end{array}$ & $\begin{array}{c}\text { Elevation } \\
\text { (ft, NAVD 88) }\end{array}$ \\
\hline 8 & 890 & 917.69 \\
\hline 9 & 1,290 & 918.69 \\
\hline 10 & 1,800 & 919.69 \\
\hline 11 & 2,450 & 920.69 \\
\hline 12 & 3,300 & 921.69 \\
\hline 13 & 4,800 & 922.69 \\
\hline 14 & 7,000 & 923.69 \\
\hline 15 & 8,900 & 924.69 \\
\hline $16^{2}$ & $110,00^{2}$ & 925.69 \\
\hline $17^{2}$ & $135,00^{2}$ & 926.69 \\
\hline $18^{2}$ & $162,00^{2}$ & 927.69 \\
\hline
\end{tabular}

${ }^{1}$ Flood profiles are 1-foot increments of stage, referenced to the gage datum of the U.S. Geological Survey streamgage, Scioto River at La Rue, Ohio (station number 03217500).

${ }^{2}$ Indicates stage and discharge estimates higher than rating 2 for Scioto River at La Rue, Ohio.
2007. The original lidar data have horizontal resolution that meets National Map Accuracy Standards (NMAS) and vertical accuracy of $\pm 1.0 \mathrm{ft}$ at a 95 -percent confidence level for the "open terrain" land-cover category (root mean squared error of $0.5 \mathrm{ft}$ ). By these criteria, the lidar data support production of 2-ft contours (Dewberry, 2012); the final DEM has a vertical accuracy of $1 \mathrm{ft}$. The DEM data from Ohio Geographically Referenced Information Program (2007) was converted into 2-ft contours by USGS personnel. By using HEC-GeoRas-a set of procedures, tools, and utilities for processing geospatial data in ArcGIS - elevation data were extracted from the DEM for 61 cross sections for use in the Scioto River HEC-RAS model. An additional 30 sections were used in the split flow analyses discussed in the "Special Hydraulic Considerations" section of this report.

Because these lidar data cannot provide ground elevations below a stream's water surface, channel cross sections were surveyed at 25 locations by USGS field crews in 2014. A differential global positioning system (DGPS) with realtime kinematic (RTK) technology was used to determine horizontal coordinates and elevations at each surveyed cross section. Elevations determined by RTK DGPS at four benchmark locations were within -0.01 to $-0.11 \mathrm{ft}$ of the known elevations.

DEM-derived cross sections were colocated with the locations of the in-channel field-surveyed cross sections where available. In those cases, in-channel data were directly merged with the DEM data. Some of the DEM-derived cross sections were at locations that did not have surveyed in-channel cross sections and, in those cases, the in-channel portions were estimated by interpolation from the closest field-surveyed cross sections.

\section{Hydraulic Structures}

Ten structures, consisting of 6 road crossings, 2 railroad bridges, and 2 low-head dams, have the potential to affect water-surface elevations during floods along the stream. Geometrical data were obtained from field surveys conducted by USGS personnel for all 10 structures in 2014. These data were collected at the same time as the benchmark information, so the relative error should be similar.

\section{Energy-Loss Factors}

Hydraulic analyses require the estimation of energy losses exerted by a channel on flow. These energy losses are quantified by the Manning's roughness coefficient (" $n$ " value). Initial (precalibration) $n$ values were selected on the basis of field observations and high-resolution aerial photographs. As part of the calibration process, initial $n$ values were adjusted until the differences between simulated and rated water-surface elevations at the streamgage (and at one additional location) were minimized. The final $n$ values ranged from 0.042 to 0.044 for the main channel and 0.07 to 0.14 for the overbank areas modeled in this analysis. 


\section{Hydraulic Model}

The HEC-RAS analysis for this study was done by using the steady-state flow computation option. Steady-state flow data consisted of flow regime, boundary conditions, and discharge estimates. Subcritical flow regime was assumed for all simulations. A water-surface slope of $0.00009 \mathrm{ft} / \mathrm{ft}$ was calculated from field surveys and used as the downstream boundary condition (normal depth). The peak flows discussed in the section "Hydrologic Data" coincided with even 1-ft increments of stage, referenced to the local gage datum.

The HEC-RAS model was calibrated to the current stage-discharge relation at the streamgage and to two locations from the December 2013 flood. One location is a high-water mark still completely visible at the time of this report, and the second was the peak stage reported at the streamgage for the December 2013 flood. Model calibration was accomplished by adjusting Manning's $n$ values and bridge contraction/expansion coefficients until the results of the hydraulic computations closely agreed with the target water-surface elevations for modeled flows. Absolute differences between observed and simulated water-surface elevations for the eight comparable simulated flows at the USGS streamgage were equal to or less than $0.45 \mathrm{ft}$ (table 3). Stages and associated discharge values above $15 \mathrm{ft}$ were not comparable. The differences between surveyed and simulated elevations of the high-water marks in the study reach for the flood of December 2013 were -0.22 and $0.01 \mathrm{ft}$ (table 4).

Table 3. Calibration of model to target water-surface elevations at U.S. Geological Survey streamgage Scioto River at La Rue, Ohio (03217500).

[ft, feet; NAVD 88, North American Vertical Datum of 1988]

\begin{tabular}{cccc}
\hline $\begin{array}{c}\text { Target } \\
\text { water-surface } \\
\text { stage } \\
\text { (ft) }\end{array}$ & $\begin{array}{c}\text { Target } \\
\text { water-surface } \\
\text { elevation } \\
\text { (ft, NAVD 88) }\end{array}$ & $\begin{array}{c}\text { Modeled } \\
\text { water-surface } \\
\text { elevation } \\
\text { (ft, NAVD 88) }\end{array}$ & $\begin{array}{c}\text { Difference } \\
\text { in elevation } \\
\text { (ft) }\end{array}$ \\
\hline 8 & 917.69 & 918.14 & 0.45 \\
\hline 9 & 918.69 & 919.04 & 0.35 \\
10 & 919.69 & 919.84 & 0.15 \\
11 & 920.69 & 920.63 & -0.06 \\
12 & 921.69 & 921.43 & -0.26 \\
13 & 922.69 & 922.51 & -0.18 \\
14 & 923.69 & 923.82 & 0.13 \\
\hline 15 & 924.69 & 924.73 & 0.04 \\
\hline
\end{tabular}

Table 4. Calibration of model to water-surface elevations at selected locations along the Scioto River for the flood of December 2013.

[ft, feet; NAVD 88, North American Vertical Datum of 1988]

\begin{tabular}{lccc}
\hline $\begin{array}{c}\text { Cross-section } \\
\text { ID (ft) }\end{array}$ & $\begin{array}{c}\text { Surveyed } \\
\text { water-surface } \\
\text { elevation } \\
\text { (ft, NAVD 88) }\end{array}$ & $\begin{array}{c}\text { Modeled } \\
\text { water-surface } \\
\text { elevation } \\
\text { (ft, NAVD 88) }\end{array}$ & $\begin{array}{c}\text { Difference } \\
\text { in elevation } \\
\text { (ft) }\end{array}$ \\
\hline 8,807 (at gage) & 923.87 & 924.09 & -0.22 \\
13,731 & 926.26 & 926.25 & 0.01 \\
\hline
\end{tabular}

${ }^{1}$ Cross-section identification numbers are referenced to the longitudinal baseline used in the hydraulic model.

\section{Special Hydraulic Considerations}

Near the upstream end of the study reach for this report, there is as east-west-oriented culvert under La Rue Kenton Road (fig. 2). In June 2014, a flood-control cap was placed on the west side of the culvert (fig. 3). This cap is designed to prevent Scioto River floodwaters from passing from the west side to the east side of La Rue Kenton Road. Without the flood-control cap, HEC-RAS model results indicate that the Scioto River could flow through this culvert near a stage of $10 \mathrm{ft}$ at the streamgage. At a stage of approximately $14 \mathrm{ft}$, La Rue Kenton Road is overtopped by floodwaters, and the modeling results are not as influenced by the flood-control cap. For all analyses in this report, it is assumed that the flood-control mechanism will work properly. If the flood-control cap fails to work properly, the flood profiles (and flood-plain boundaries shown) would result in different inundated areas than those shown for stages between $10 \mathrm{ft}$ and $13 \mathrm{ft}$, inclusive.

\section{Split Flow Analyses}

Preliminary HEC-RAS model results indicated that floodwaters from the Scioto River would flow over the La Rue Kenton Road near the culvert described earlier (fig. 2) at stage $14 \mathrm{ft}$ and above at the Scioto River at La Rue, Ohio, streamgage. This split flow (discharge) would separate from the main channel moving easterly then southerly through $\mathrm{La}$ Rue along the flow path labeled A-B (fig. 4) until eventually returning to the main channel of the Scioto River. A split flow analysis was used in the HEC-RAS model, employing a junction, to apportion the streamflow between the main channel and split flow reaches for all stages above $13 \mathrm{ft}$. An iterative modeling technique was used to apportion a percentage of the total discharge of the Scioto River and route it down the split flow path until a common water-surface elevation for the two reaches was obtained near location A (fig. 4). The split-flow analyses indicate that between 8.6 and 10.0 percent of the total discharge will be diverted through La Rue along the split flow path (table 5) for stages above $13 \mathrm{ft}$. 
$83^{\circ} 24^{\prime}$

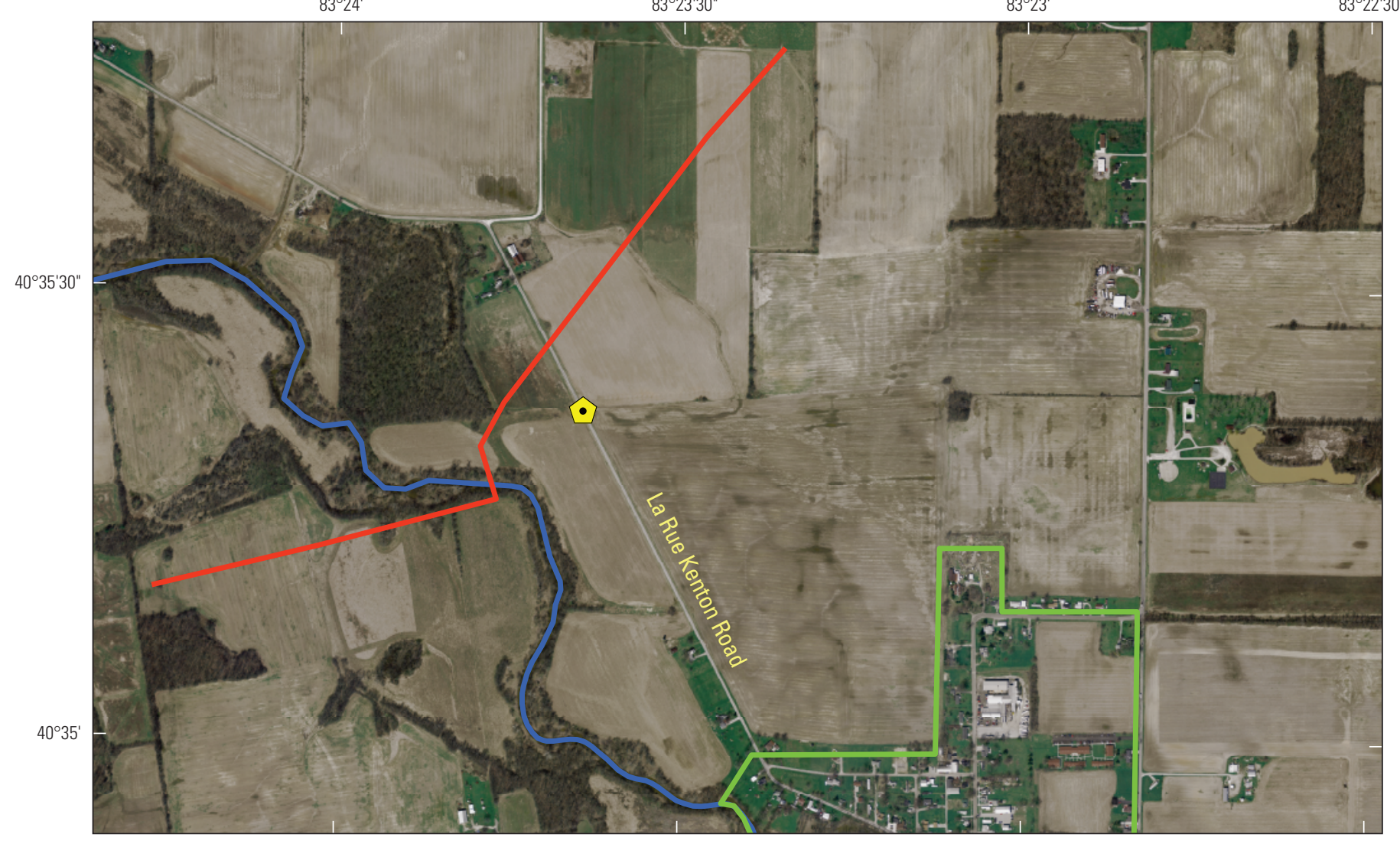

Base variously scaled, 2007 orthophotography from Ohio Department of Adminstrative Services,

Office of Information Technology, Ohio Geographically Referenced Information Program, Ohio

Statewide Imagery Program, 2006 State Plane projection (feet), Ohio North. Horizontal coordinate

information is referenced to the North American Datum of 1983 (NAD 83)

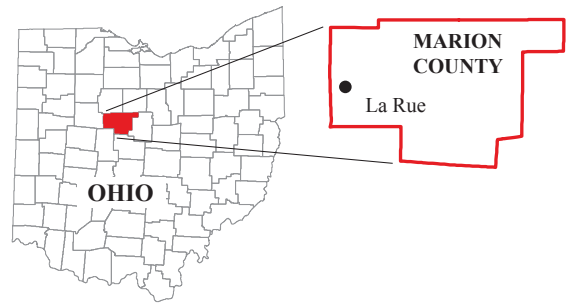

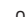

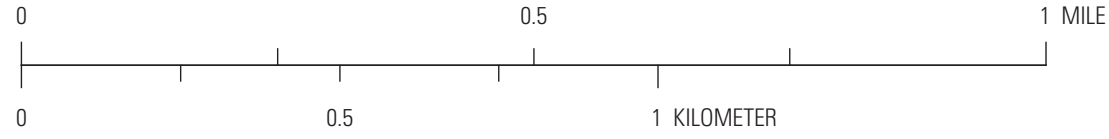

EXPLANATION

La Rue, Ohio

Study limits

Scioto River

$\bullet \quad$ Culvert

Figure 2. Location of overflow culvert near upper end of study reach. 


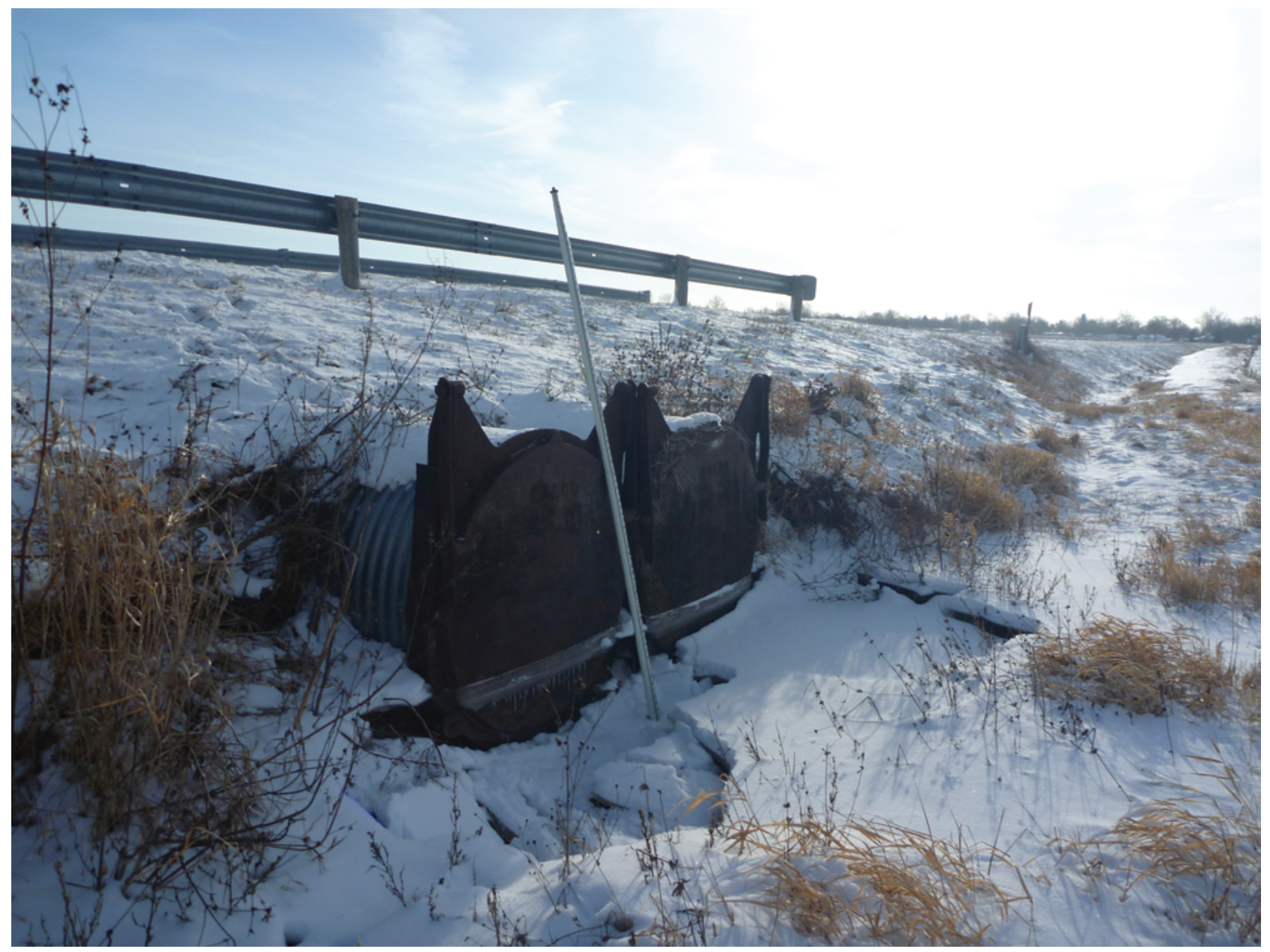

Figure 3. Photograph of flood-control cap on west side of La Rue Kenton Road. (Photo by U.S. Geological Survey personnel, January 2015.)

\section{Development of Flood Profiles}

The calibrated HEC-RAS model was used to generate profiles for a total of 11 stages at 1-ft intervals between $8.0 \mathrm{ft}$ and $18.0 \mathrm{ft}$ as referenced to the local datum of the Scioto River at La Rue streamgage. Discharges corresponding to the various stages were obtained from the current stage-discharge relation for the Scioto River at La Rue streamgage.

\section{Development of Flood-Inundation Maps}

Flood-inundation maps were created in a GIS for the 11 flood profiles by combining flood-profile data with digital elevation data. The DEM was derived from the lidar data described previously in the section "Topographic and Bathymetric Data" and has an estimated vertical accuracy of $1 \mathrm{ft}$. Initial flood-inundation boundaries were developed for each simulated profile by use of HEC-GeoRas software (U.S. Army
Corps of Engineers, 2009). Flood-inundation boundaries and depth grids for the inundated areas were modified in ArcMap (Esri, 2015), as required, to ensure hydraulically reasonable transitions of the flood boundaries between modeled cross sections.

Any inundated areas that were disconnected from the main channel were examined to identify artificial connections with the main river, such as through culverts under roadways. Where such connections existed, the mapped inundated areas were retained in their respective flood maps; otherwise, the disconnected inundated areas were deleted. The flood-inundation areas were overlain on high-resolution, georeferenced aerial photographs of the study area. Estimates of water depths can be determined from the depth-grid data that are included with the flood-inundation maps on the USGS mapping application described in the following section, "Flood-Inundation Map Delivery." The flood-inundation map corresponding to the highest simulated water-surface profile is shown in figure 5. 


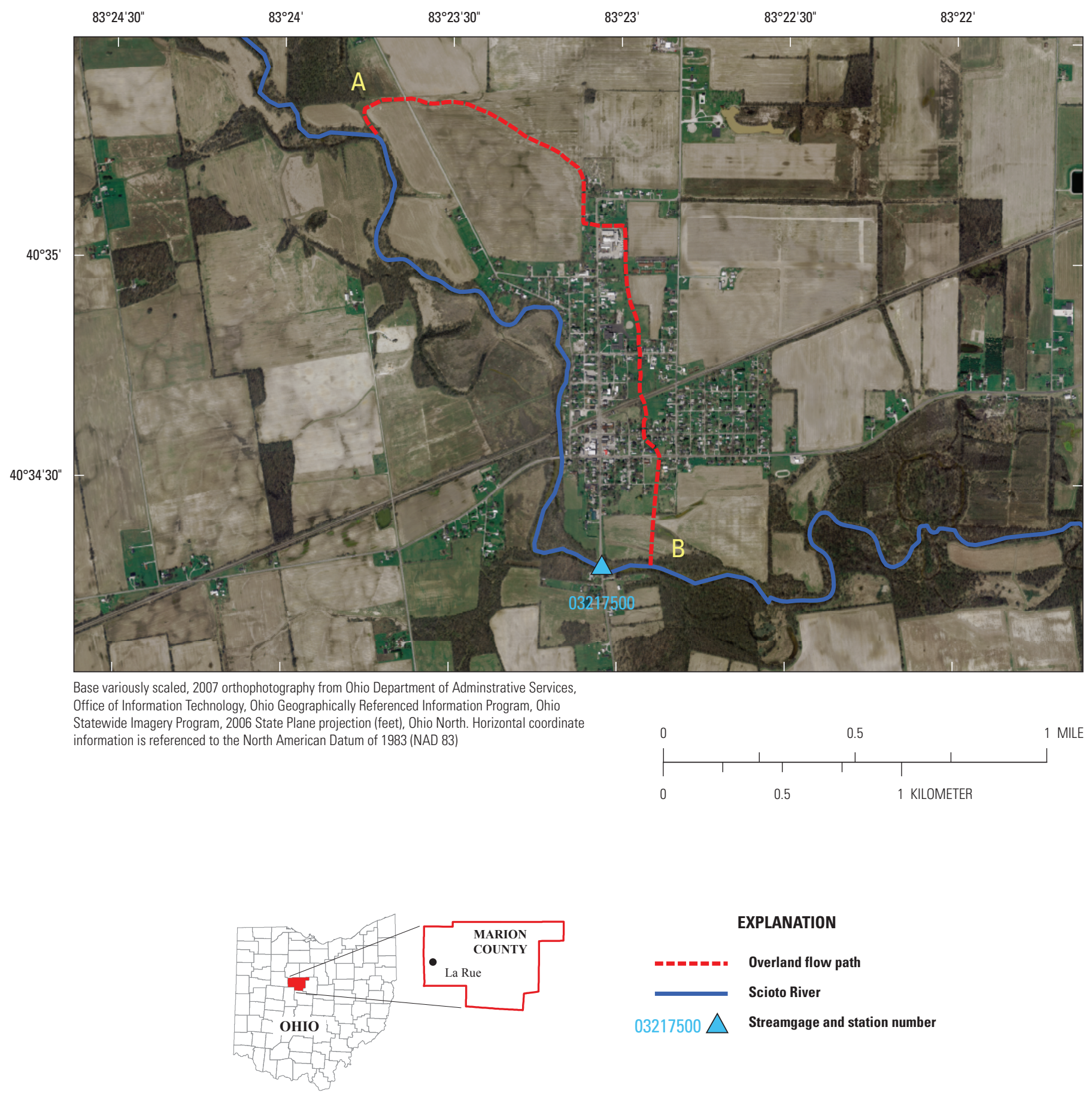

Figure 4. Representation of split flow analyses for Scioto River at La Rue, Ohio, streamgage. 
Table 5. Flow apportionment for split flow analyses for HEC-RAS model for stages at Scioto River at La Rue, Ohio, streamgage.

[ft, feet; $\mathrm{ft}^{3} / \mathrm{s}$, cubic feet per second]

\begin{tabular}{ccccc}
\hline $\begin{array}{c}\text { Stage } \\
(\mathbf{f t})\end{array}$ & $\begin{array}{c}\text { Estimated } \\
\text { main-channel } \\
\text { discharge } \\
\left(\mathbf{f t}^{3} / \mathbf{s}\right)\end{array}$ & $\begin{array}{c}\text { Estimated } \\
\text { overflow-channel } \\
\text { discharge } \\
(\mathbf{f t} / \mathbf{s})\end{array}$ & $\begin{array}{c}\text { Total discharge } \\
\text { estimate } \\
\left(\mathbf{f t}^{3} / \mathbf{s}\right)\end{array}$ & $\begin{array}{c}\text { Overflow-channel } \\
\text { discharge as a } \\
\text { percentage of } \\
\text { total discharge } \\
\text { estimate } \\
\text { (percent) }\end{array}$ \\
\hline 14 & 6,300 & 700 & 7,000 & 10.0 \\
\hline 15 & 8,070 & 830 & 8,900 & 9.3 \\
\hline 16 & 9,970 & 1,030 & 11,000 & 9.4 \\
\hline 17 & 12,300 & 1,200 & 13,500 & 8.9 \\
\hline 18 & 14,850 & 1,350 & 16,200 & 8.3 \\
\hline
\end{tabular}

\section{Flood-Inundation Map Delivery}

A Flood Inundation Mapping Science (FIMS) Web site (U.S. Geological Survey, 2015c) has been established to serve USGS flood-inundation study information available to the public. The FIMS site has a mapping application that can display detailed information on flood extents and depths for modeled sites. The FIMS Web site contains a link to NWISWeb, which displays the most recent stage and streamflow at the USGS streamgage at La Rue (03217500). A second link points to the NWS Advanced Hydrologic Prediction Service (AHPS) site (National Weather Service, 2015a) where the user can obtain information on forecasted peak stage. The estimated flood-inundation maps are displayed in sufficient detail so that preparations for flooding and decisions for emergency response can be performed efficiently. Depending on the flood magnitude, roadways are shown as shaded (inundated and likely impassable) or not shaded (dry and passable) to facilitate emergency planning and use. A shaded building does not necessarily mean that the structure is completely submerged; rather, it may mean that bare-earth surfaces in the vicinity of the building are inundated.

\section{Disclaimer for Flood-Inundation Maps}

The flood-inundation maps should not be used for navigation, regulatory, permitting, or other legal purposes. The USGS provides these maps "as-is" for a quick reference, emergency planning tool but assumes no legal liability or responsibility resulting from the use of this information.

\section{Uncertainties and Limitations Regarding Use of Flood-Inundation Maps}

Although the flood-inundation maps represent the boundaries of inundated areas with a distinct line, some uncertainty is associated with these maps. The flood boundaries shown were estimated on the basis of water stages and streamflows at a selected USGS streamgage. Water-surface elevations along the stream reaches were estimated by steady-state hydraulic modeling, assuming unobstructed flow, and using streamflows and hydrologic conditions anticipated at the USGS streamgage. The hydraulic model reflects the land-cover characteristics and any bridge, dam, levee, or other hydraulic structures existing as of March 2015. Unique meteorological factors (timing and distribution of precipitation) may cause actual streamflows along the modeled reach to vary from those assumed during a flood, which may lead to deviations in the water-surface elevations and inundation boundaries shown. Additional areas may be flooded due to unanticipated conditions such as changes in the streambed elevation or roughness, backwater into major tributaries along a main stem river, or backwater from localized debris or ice jams. The accuracy of the floodwater extent portrayed on these maps will vary with the accuracy of the digital elevation model used to simulate the land surface.

If this series of flood-inundation maps will be used in conjunction with National Weather Service (NWS) river forecasts, the user should be aware of additional uncertainties that may be inherent or factored into NWS forecast procedures. The NWS uses forecast models to estimate the quantity 


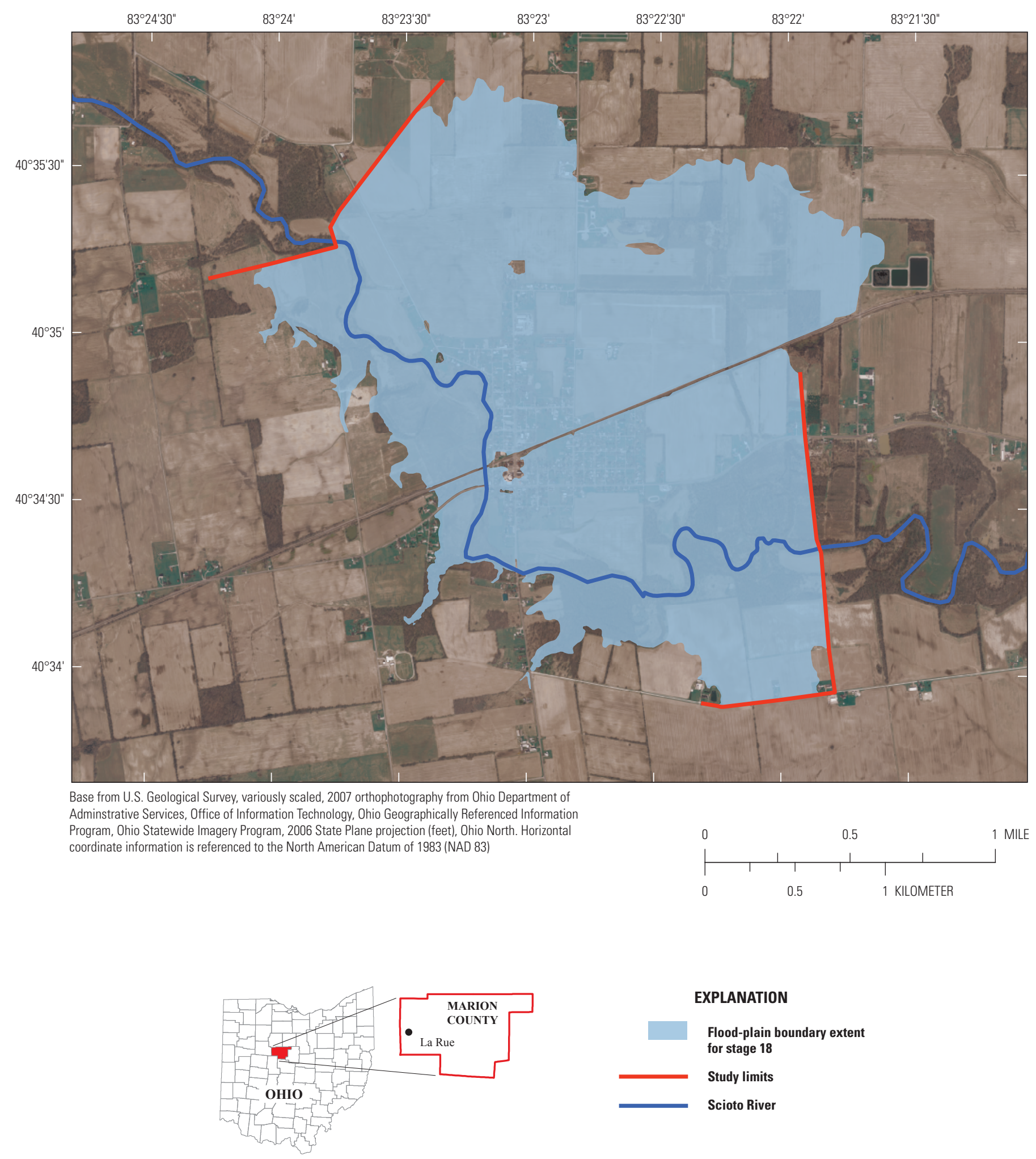

Figure 5. Flood-inundation map for the Scioto River at La Rue, Ohio, corresponding to a stage of 18.0 feet at the U.S. Geological Survey streamgage (03217500). 
and timing of water flowing through selected stream reaches in the United States. These forecast models (1) estimate the amount of runoff generated by precipitation and snowmelt, (2) simulate the movement of floodwater as it proceeds downstream, and (3) predict the flow and stage (and water-surface elevation) for the stream at a given location (AHPS forecast point) throughout the forecast period (every 6 hours and 3 to 5 days out in many locations). For more information on AHPS forecasts, please see http://water.weather.gov/ahps/pcpn_and river_forecasting.pdf. Additional uncertainties and limitations pertinent to this study are described elsewhere in this report.

\section{Summary}

The USGS, in cooperation with the Village of La Rue, Marion County Commissioners, Montgomery Township, and Marion County Scioto River Conservancy developed a series of 11 digital flood-inundation maps for the Scioto River at La Rue. The maps cover a 3-mile (mi) reach of the Scioto River, extending about $1 / 2$ mi upstream and a $1 / 2$ mi downstream from the corporate limits of La Rue.

The U.S. Army Corps of Engineers' HEC-RAS and HEC-GeoRAS programs were used to compute water-surface profiles and to help delineate estimated flood-inundation areas and depths of flooding for selected stream stages. The HEC-RAS hydraulic model was calibrated by using the current stage-discharge relation at the Scioto River at La Rue, Ohio, streamgage and two locations: the streamgage itself and a single high-water mark from a flood in December 2013. The model was used to compute 11 water-surface profiles for flood stages ranging from 8.0 feet (ft) (near bankfull) to $18.0 \mathrm{ft}$ (higher than the historical peak of record) in 1-ft intervals. The simulated water-surface profiles were then used in combination with a digital elevation model (DEM) derived from lidar data to delineate estimated flood-inundation areas and depth grids. These flood-inundation areas were overlain on high-resolution, georeferenced aerial photographs of the study area. The flood maps are available through a mapping application that can be accessed on the USGS Flood Inundation Mapping Science Web site (http://water.usgs.gov/osw/ flood_inundation).

Interactive use of the maps on this mapping application can give users a general indication of depth of water at any point by using the mouse cursor to click within the shaded areas. These maps, in conjunction with the real-time stage data from the USGS streamgage, Scioto River at La Rue, Ohio (station number 03217500), and forecasted flood stage data from the National Weather Service Advanced Hydrologic Prediction Service can help emergency planners and the public make more informed decisions about flood risk.

\section{References Cited}

Dewberry, 2012, National Enhanced Elevation Assessment: Fairfax, Va., 84 p., accessed July 9, 2013, at http:// www.dewberry.com/files/pdf/NEEA Final\%20Report Revised\%203.29.12.pdf.

Esri, 2015, ArcGIS, accessed January 5, 2015, at http://www. esri.com/software/arcgis/.

Federal Emergency Management Agency, 2010, Flood Insurance Study, Marion County, Ohio, and incorporated areas, dated July 6, 2010; Washington D.C., 28 p.

National Weather Service, 2015a, Advanced Hydrologic Prediction Service, Scioto River at La Rue, accessed January 5, 2015, at http://water.weather.gov/ahps2/hydrograph. php? wfo $=$ cle\&gage $=$ lar0 1 .

National Weather Service, 2015b, National Weather Service glossary, accessed January 6, 2015, at http://w1.weather. gov/glossary/index.php?word=action+stage.

Ohio Geographically Referenced Information Program, 2007, Ohio Statewide Imagery Program, accessed March 2, 2015 , at http://ogrip.oit.ohio.gov/ProjectsInitiatives/ OSIPDataDownloads.aspx.

U.S. Army Corps of Engineers, Hydrologic Engineering Center, 2009, HEC-GeoRas, GIS tools for support of HECRAS using ArcGIS_-User's manual, version 4.2 [variously paged].

U.S. Army Corps of Engineers, Hydrologic Engineering Center, 2010, HEC-RAS River Analysis System, Hydraulic reference manual, version 4.1 [variously paged].

U.S. Bureau of Census, 2013, State population datasets: Population estimates accessed November 24, 2014, at http:// www.census.gov/popest/data/index.html.

U.S. Geological Survey, 2015a, USGS 03217500 Scioto River at La Rue: U.S. Geological Survey National Water Information System, accessed January 5, 2015, at http://waterdata. usgs.gov/oh/nwis/inventory/?site_no $=03217500$.

U.S. Geological Survey, 2015b, USGS surface-water data for the Nation: U.S. Geological Survey National Water Information System, accessed January 5, 2015, at http:// waterdata.usgs.gov/nwis/sw.

U.S. Geological Survey, 2015c, USGS Flood Inundation Mapping Science: U.S. Geological Survey Web site, accessed January 5, 2015, at http://water.usgs.gov/osw/flood inundation. 
Publication services provided by the U.S. Geological Survey Science Publishing Network

Columbus Publishing Service Center

West Trenton Publishing Service Center

For more information concerning the research in this report contact the

Director, Ohio Water Science Center

6480 Doubletree Ave

Columbus, $\mathrm{OH}$ 43229-1111

http://oh.water.usgs.gov/ 


\section{$\frac{1}{8}$}

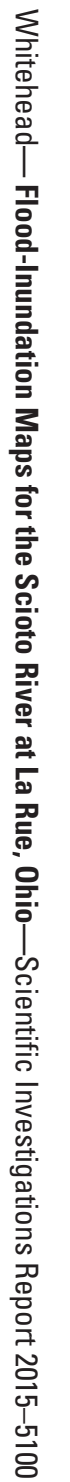

